MODERN TRENDS IN FORENSIC MEDICINE 2nd series. Edited by K. Simpson. (Pp. $x+374$; illustrated. 98s.)

London: Butterworths. 1967.

The first series of Modern trends in forensic medicine was published in 1953 and, like the volume now reviewed, was edited by Professor Keith Simpson. It is not a revision and the two books are complementary.

Thirteen subjects are discussed and all are worth attention. Much is happening in this field, and a chapter by Professor Gilbert Forbes on the organization, staffing, and equipment of an institute of forensic medicine is timely and contains much wisdom. His remarks about the deficiences in the clinical side of this subject are undoubtedly true and should be noted by police authorities, especially in rural areas.

Professor Keith Simpson writes on two important subjects. In his chapter on the pattern of traffic accidents information is given which should be helpful to all those, including lawyers and the police, who have to try to assess what actually happened in a given road accident. It is a sobering thought that traffic accidents cause 7,000 deaths and 350,000 cases of injury in Britain each year. The statistical analysis of the accidents is worthy of study.

The chapter by Professor Simpson on the pathology of the myopathies is a useful summary of what many morbid anatomists find a very difficult subject.

Dr. Keith Mant writes on post-mortem changes and timing death and also on the pathology of hypothermia. Dr. G. R. Osborn gives a critical and interesting review of coronary disease which includes much of his own research into this subject.

The legal application of blood group systems was dealt with in the earlier series, but in this book Dr. Alan Grant brings the subject up to date, and it seems amazing that Parliament has not found time to pass legislation requiring the application of blood grouping to affiliation problems.

Other subjects discussed are photography in crime investigation, forensic immunology, the pathology of the foetus and infant, and mishaps of modern therapeutics. A final chapter by W. H. D. Winder, a barrister, on civil liability and the law of evidence gives the present position on matters which are of importance to all doctors.

This is a good and important book and is well produced but, perhaps, a little expensive. It is essential for forensic pathologists and should be in the possession of all pathologists doing hospital or coroners' necropsies.

G. STEWART SMITH

HANDBOOK OF EXPERIMENTAL PHARMACOLOGY VOL. 16, SECTION 15 By E. Eichenberger, P.P. Foa, and T.A.I. Grillo. (Pp. xii +472 ; 94 figures. DM 136.) Berlin: Springer-Verlag. 1966.

In volume 16, section 15 of the Handbuch der Experimentellen Pharmakologie the study of 'Carbohydrate metabolism' is discussed by P. P. Foa of Detroit, and 'Fever and endogenous hyperthermia...' by $E$.
Eichenberger of Berne. The first of the two articles is in English, the second is in German.

Foa's contribution is concerned mainly with biolo gical and chemical methods currently or formerly used in the experimental study of carbohydrate metabolism in laboratory animals and in man, and with their interpretation in terms of physiological or clinical significance. Histological and histochemical methods for investigating the endocrine pancreas are discussed in 13 pages by Foaand A. I. Grillo.

The scope of the presentation is wide and literature $\vec{\overrightarrow{ }}$ quoting extensive, though not exhaustive. The material $\omega$ is presented clearly and concisely-factually rather than critically.

It is inevitable in a volume of this size, especially in sorapidly expanding a field, that the most recent con-tributions to knowledge are not included: 1,587 references $-\vec{A}$ are cited in the main text and an addendum, completed $\vec{\infty}$ on 31 January 1965-little more than 18 months after the main work-contains references to a further 650 윽 publications in the field of carbohydrate metabolism, and only a slightly smaller number of references are cited by Eichenberger.

The book is a mine of information but first and foremost it is a source book rather than a working manual. It would repay study by anyone entering the fields of $\vec{c}$ scientific investigation dealt with within its covers and should have a place on the bookshelf of the established investigator for reference. Its use to the practisingo clinical pathologist, however, is likely to be limited. VINCENT MARKS

\section{Journal of Medical Microbiology}

A new journal, the Journal of Medical Microbiology is soon to be established by the Pathological Society of $\frac{O}{3}$ Great Britain and Ireland. The aim will be to publish papers on all aspects of microbiology-bacteriology, protozoology, virology, mycology, and immunologyinsofar as they are applicable to human or veterinary응 medicine, and advance knowledge in these fields. Papers:that include clinical or epidemiological observations, 3 as well as the results of laboratory work, will be welcome, particularly if they help to define diseases caused by윽 individual microorganisms, to improve methods of

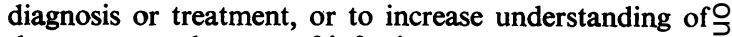
the sources and routes of infection.

It is expected that the first issue will appear in August 1968. The price will be $17 / 6$ per issue, or $£ 3$ for the four issues to be published every 12 months, on the assumption o that there will be about 64 pages per issue: the price may have to be adjusted if the number of papers printed $\mathrm{N}$ increases.

The Editors will be C. L. Oakley, S. D. Elek, M. T. Parker, J. P. Duguid, and J. G. Collee. All manuscriptse should be sent to Professor C. L. Oakley, School of $\frac{}{\mathbb{C}}$ Medicine, Leeds 2, with a clear statement that they are intended for the Journal of Medical Microbiology. 